\title{
The Importance of Cockroaches
}

\section{Cardoso da Silva LDO*}

Federal University of Rio de Janeiro, Brazil

*Corresponding author: Leonardo de Oliveira Cardoso da Silva, Federal University of Rio de Janeiro, General Herculano Gomes street, 1340 - São Cristóvão, Rio de

\section{Editorial}

Volume 2 Issue 5

Received Date: October 17, 2019

Published Date: October 31, 2019

DOI: $10.23880 /$ izab-16000183

Janeiro - RJ, Botanic Garden, Library building, Brazil, Tel: (21)97513-2391; Email: locsbio@hotmail.com

\section{Editorial}

Cockroaches, including termites from epifamily Termitoidea (order Blattodea), have the second largest number of species compared to other Polyneoptera, approximately 7,570 described species, of which 4,641 are cockroaches [1]. Linnaeus, et al. [2] considered cockroaches within the order Coleoptera, in a single genus called Blatta, which in Latin means bookworm. The same author added that cockroaches in Russia and Finland consume bread as well as clothing, forcing residents to leave their homes and return only in the middle of winter, when cockroaches perish from the cold [3]. According to the authors, perhaps this is why cockroaches are popularly referred to as pests, but these insects are not as malignant as they are portrayed in movies, magazines, and the popular imagination. In fact cockroaches do better than we think.

These insects can be found on all continents, but usually inhabit the tropical region because these places have conditions suitable (temperature and humidity) to most living species today. They are present in the litter, under rotting logs, in the treetops, in hives, anthills and termite mounds, and even in caves. They are individuals that contribute to insect biomass because they are food sources for insectivorous animals and probably help in nutrient cycling in the ecosystem, as many cockroaches, although omnivorous, prefer decomposing plant matter and their feces mix with the soil. There are still some who have been observed acting as pollinators when feeding on pollen grains.

It is noteworthy that to combat the bad reputation that cockroaches have, it becomes necessary to disseminate scientific actions not only to the scientific community, but to society in general, either through events held by research institutions or even actions aimed at bring this knowledge directly to classrooms, a role mediated between researchers with elementary and high school teachers.

\section{A Brief History of the Order}

Olivier, e al. [4] created the order Orthoptera and also inserted in it the genus Blatta. Subsequently, Leach [5] moved as a low price to a group he is called Dictuopter, later corrected to Dictyoptera de Navas. Serville, et al. [5] in a work on an Orthoptera order, created a Blattaria order and included 10 genera and 80 species. Later Brunner von Wattenwyl, et al. [6] created the subordinate Blattodea to group all tariffs. Mckittrick, et al. [7] from a comparative study of female and male genitalia and their musculature, considered the term Blattaria as suborder. Only Mackerras, et al. [8] onsidered, by his study, Blattodea as order [9].

\section{References}

1. Beccaloni GW, Eggleton P (1882) Order Blattodea Brunner von Wattenwyl. In: Zhang ZQ, et al. (Eds.), Animal biodiversity: An outline of higher-level classification and survey of taxonomic richness. Zootaxa 3148: 199-200.

2. Linnaeus C (1758) Systema Naturae per regna tria naturae. $10^{\text {th }}$ (Edn.), Leipzig: Holmiae: Laurentii Salvii.

3. Engel Ledeboer MSJ, Engel H (1964) Carolus Linnaeus Systema Naturae 1735: Facsimile of the First Edition: With an introduction and a first English translation of 


\section{International Journal of Zoology and Animal Biology}

the "Observationes". Amsterdam, Nieuwkoop o B. de Graaf.

4. Olivier AG (1789) Encyclopédie méthodique histoire naturelle: Dictionaire dês insectes. Paris: Jacques Thevin pp: 89-98.

5. Serville JGA (1839) Histoire Naturelle des Insectes: Orthoptères. Paris: Roret.

6. Brunner Von Wattenwyl K (1882) Prodromus der Europaischen Orthopteren. Leipzig: Wilhelm Engelmann.
7. Mckittrick FA (1964) Evolutionary Studies of Cockroaches. Cornell University Agricultural New York State College of Agriculture Memoir 389: 1-197.

8. Mackerras MJ (1979) Blattodea (Cockroaches). In: The Insects of Australia, Camberra: Melbourne University pp: 262-274.

9. Navás L (1905) Mis excursiones durante el verano de 1904. Boletín de la Sociedad Aragonesa de Ciencias Naturales 4(45): 107-135. 